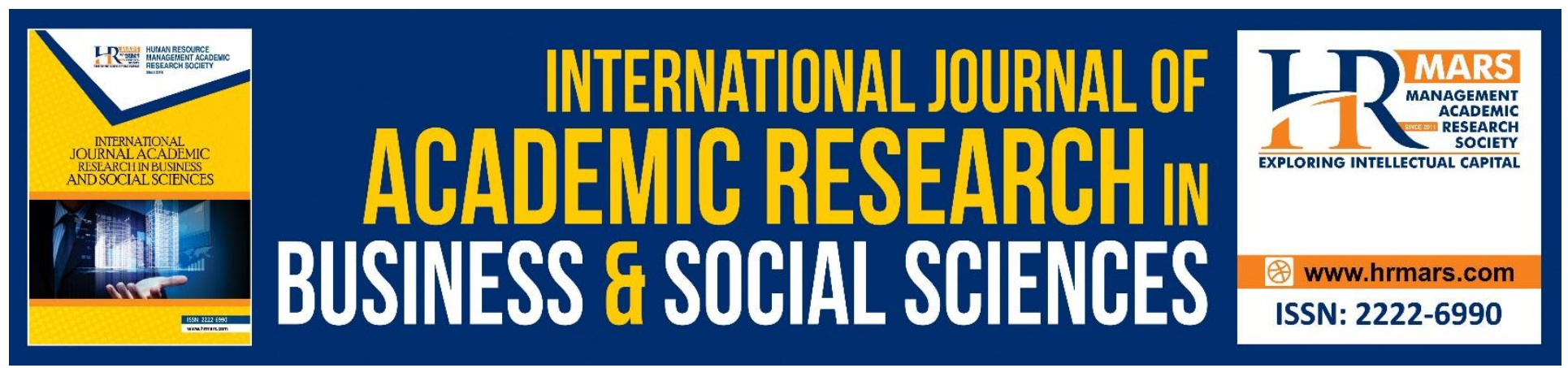

\title{
International Students' Satisfaction Level towards Service Quality in Academic Aspect and Loyalty to Universiti Teknologi Malaysia
}

\author{
Mun Chong Sin, Bin Boon Yusof, Kit Yeng Sin
}

To Link this Article: http://dx.doi.org/10.6007/IJARBSS/v8-i10/4783

DOI: $10.6007 /$ IJARBSS/v8-i10/4783

Received: 04 Sept 2018, Revised: 13 Oct 2018, Accepted: 19 Oct 2018

Published Online: 28 October 2018

In-Text Citation: (Sin, Yusof, \& Sin, 2018)

To Cite this Article: Sin, M. C., Yusof, B. B., \& Sin, K. Y. (2018). International Students' Satisfaction Level towards Service Quality in Academic Aspect and Loyalty to Universiti Teknologi Malaysia. International Journal of Academic Research in Business and Social Sciences, 8(10), 838-850.

Copyright: (c) 2018 The Author(s)

Published by Human Resource Management Academic Research Society (www.hrmars.com)

This article is published under the Creative Commons Attribution (CC BY 4.0) license. Anyone may reproduce, distribute, translate and create derivative works of this article (for both commercial and non-commercial purposes), subject to full attribution to the original publication and authors. The full terms of this license may be seen at: http://creativecommons.org/licences/by/4.0/legalcode

Vol. 8, No. 10, 2018, Pg. 838 - 850

Full Terms \& Conditions of access and use can be found at http://hrmars.com/index.php/pages/detail/publication-ethics 


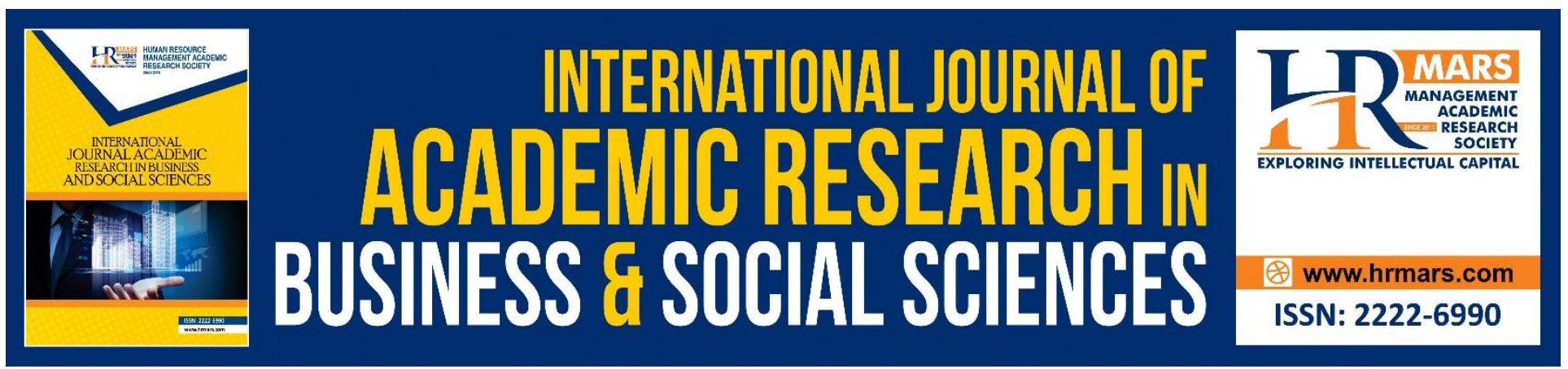

\title{
International Students' Satisfaction Level towards Service Quality in Academic Aspect and Loyalty to Universiti Teknologi Malaysia
}

\author{
${ }^{1}$ Mun Chong Sin, ${ }^{2}$ Bin Boon Yusof, ${ }^{3}$ Kit Yeng Sin \\ 1\&2Universiti Teknologi Malaysia (UTM), School of Education, Faculty of Social Science and \\ Humanities, 81100 Johor Bahru, Johor, Malaysia. \\ ${ }^{3}$ University Malaysia Perlis (UniMAP), School of Business Innovation \& Technopreneurship, 01000 \\ Kangar, Perlis, Malaysia. \\ Corresponding Author: simonsinmunchong@gmail.com
}

\section{ABSTRACT}

In recent years, the number of international students has increased greatly in Universiti Teknologi Malaysia (UTM). Despite the international dimension of higher education gaining more importance nowadays, there have been limited studies exploring the satisfaction of the international students. Therefore, the purpose of this study was to identify the international students' satisfaction level towards the service quality in UTM. In addition, this study aimed to investigate the relationship between the students' satisfaction level and their loyalty. A quantitative research methodology was adopted whereby a questionnaire consisting of three parts was utilized: Part A described the demographic data of the samples; Part B (44 items) investigated the international students' satisfaction level which was adopted from the Parasuraman's SERVQUAL model and; Part C (10 items) identified the students' loyalty. A total of 334 international students studying in UTM, Johor Bahru Campus participated in the questionnaire and the results were analyzed using descriptive statistics, Pearson correlation, and multiple regression analysis. The findings showed that international students were not satisfied with the service quality provided in UTM. The expectation score was greater than the perception score in five dimensions of SERVQUAL model, namely tangibles, reliability, responsiveness, assurance, and empathy. Furthermore, multiple regression analysis results showed that responsiveness, assurance, and empathy were the three dimensions which had significant relationship with the students' loyalty. In conclusion, the findings of this study suggested that the administrators of UTM should improve the service quality in UTM to increase the students' satisfaction.

Keywords: Students' satisfaction, Students' loyalty, SERVQUAL, Service quality, Academic aspect 
INTERNATIONAL JOURNAL OF ACADEMIC RESEARCH IN BUSINESS AND SOCIAL SCIENCES

Vol. 8, No. 10, Oct. 2018, E-ISSN: 2222-6990 @ 2018 HRMARS

\section{INTRODUCTION}

In line with the 'Ninth Malaysia Plan', the Malaysian government has aspired to become a regional higher education centre since 2006 to attract more foreign students (Down, 2009). The Ministry of Higher Education (MoHE) in Malaysia has targeted to attract 200,000 international students by the year 2020 (MoHE 2007). As a result, the population of foreign students has increased from 580 in 1995 to 93,000 students in 2010, causing Malaysia to be ranked $11^{\text {th }}$ in the same year based on the population of students (The Edge 2011).

As with all other service industries, service quality is the key to success for higher education sector (Rezaei, Matin, Hajizadeh, Soroush, Mohammadi, Babakhany and Jamshidi 2017). According to Parasuraman, Zeithhalm, and Berry (1988), the service of an institution is judged with different dimensions and its quality could determine how satisfied a customer is (Galeeva 2016). The customers would naturally feel more satisfied if the service quality they perceive is higher. Furthermore, based on the research conducted by Dehghan,Dugger, Dobrzykowski and Balazs (2014), the expectations of the customers connect with their perception of the service quality, and thus the customers' loyalty could be influenced by the quality of a service.

This study was conducted at UTM, Johor Bahru, which is one of the research universities in Malaysia. According to the MoHE in Malaysia (2013), the number of international students studying in UTM has been increasing over the years. In 2015, the total number of undergraduate, postgraduate, and PhD students in UTM was 29,881. Among these students, 5175 (17.32\%) were international students who came from 65 different countries including Iran, Nigeria, Pakistan, Yamen, and Indonesia (ISC UTM 2015).

It is essential to attract more international students as their existence could provide numerous benefits to both the country and the institutions. Among which, international students contribute greatly to the nation's economy. For instance, the tuition fees of the international students which are generally higher than that of the local students could be a considerable profit to the institutions (Facts and Figures, UTM's website 2015). Furthermore, if the international students further pursue their study at the higher education institutions, they would continue to become one of the important sources of income to the universities. Therefore, it is crucial to explore the learning experience and satisfaction of the international students as their satisfaction is directly linked to their loyalty to the institutions (Bolliger \& Wasilik 2009). Besides financial benefits, skills and ability in their study area could be delivered into the institutions and enhance the learning experience (NUS, 2016).

Students' loyalty is defined as the ability of an educational organization to attract new students to study in the university and retain the current students (Galeeva 2016). Often, the institutions compete to retain their current students rather than attracting and enrolling the new students. According to Chong and Ahmed (2012), it is because familiar customers are more efficient to deal with and it is five-time costlier to acquire a new customer than to retain a current customer. Thus, higher education institutions should determine the variables influencing the students' loyalty and develop strategies to retain more of their existing students (Dehghan et al. 2014).

A literature search in the UTM library revealed limited studies which examined the international students' satisfaction and the service quality factors influencing their satisfaction level at the university level. Most of the existing studies investigated the customers' satisfaction level in other services, such as hostel, library, and healthcare. Therefore, this research was conducted to 
determine the satisfaction level of the international students towards the service quality of UTM in relation to the academic aspects. Furthermore, the relationship between the students' satisfaction level and their loyalty was explored.

In essence, evaluating the satisfaction of the UTM international students towards the quality of services provided by the university would allow the university to improve their service quality accordingly. International students are an important source of income to the university and their presence should be retained. By enhancing the service quality, the retention of the international students studying in UTM could be increased. More importantly, this research could potentially increase the number of international students in UTM by investigating the relationship between the students' satisfaction and their loyalty. In addition, this research could contribute to the existing literature and serve as a reference for future research.

\section{Service Quality}

Service quality is linked to the customers' expectations and their perception of the service offered by a company (Wong, Tunku and Rahman 2012). It is a result of the customers' comparison of their expectation of a service with the real perception of the service or product consumed by them. Thus, there is a need to compare these two factors to measure the customers' satisfaction. A service or product is considered excellent if the perceptions are higher than the expectations. However, if the expectations are equal to the perceptions, it is considered good. When the perceptions do not meet the expectations, it is considered a poor service. 
INTERNATIONAL JOURNAL OF ACADEMIC RESEARCH IN BUSINESS AND SOCIAL SCIENCES Vol. 8, No. 10, Oct. 2018, E-ISSN: 2222-6990 @ 2018 HRMARS

Figure 1 Model of Service Quality Gaps (Parasuraman et al. 1985; Curry 1999; Luk and Layton 2002)

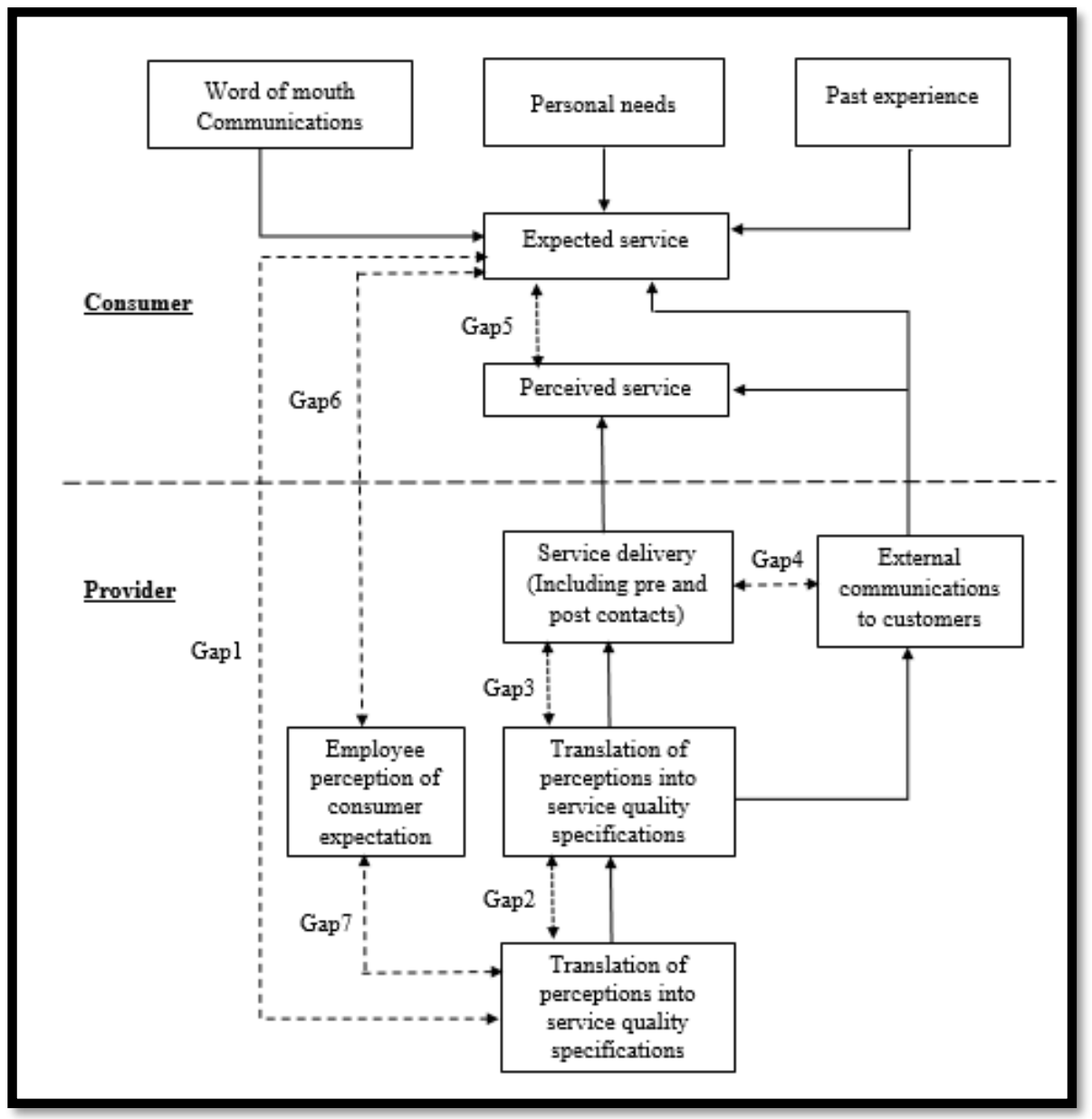

According to Brown and Bond (1995), the model of service quality gaps, as shown in Figure 1, identifies seven gaps relating to the managerial perceptions of service quality and the tasks associated with the service delivery to the customers. Gap 1, Gap 2, Gap 3, Gap 4, Gap 6, and Gap 7 are identified as the functions of the way in which a service is delivered, whereas Gap 5 pertains to the customer and it is the true measure of the service quality.

\section{Parasuraman SERVQUAL (1991)}

SERVQUAL is an instrument which was developed by Parasuraman, Zeithaml, and Berry in 1988 to measure the service quality. This instrument consists of ten dimensions of service quality which include tangibles, responsiveness, reliability, competency, communication, credibility, courtesy, security, access, and understanding. These ten dimensions could measure the service quality based on the inputs from the focus group. Furthermore, SERVQUAL is used widely to measure the service quality of different organizations, such as hospital, libraries, and bank services (Narang 2012). As displayed in Table 1, the ten dimensions are then shortlisted into five dimensions, which is known as the RATER. These five dimensions are the basis of the higher education quality dimensions to evaluate the customers' expectations and perceptions of the service quality.

Table 1 Five SERVQUAL Dimensions Shortlisted by Parasuraman and Berry (1991) 
INTERNATIONAL JOURNAL OF ACADEMIC RESEARCH IN BUSINESS AND SOCIAL SCIENCES Vol. 8, No. 10, Oct. 2018, E-ISSN: 2222-6990 @ 2018 HRMARS

\begin{tabular}{|c|l|}
\hline Dimensions & \multicolumn{1}{|c|}{ Explanation } \\
\hline Reliability & $\begin{array}{l}\text { The ability of the staff to provide service dependably, accurately, and } \\
\text { consistently. }\end{array}$ \\
\hline Assurance & $\begin{array}{l}\text { The staff own knowledge and skills where their service and product are } \\
\text { trustable. }\end{array}$ \\
\hline Tangibles & $\begin{array}{l}\text { The physical facilities and equipment of the company and the physical } \\
\text { appearance of the staff. }\end{array}$ \\
\hline Empathy & $\begin{array}{l}\text { The staff could provide caring and individualized attention to specified } \\
\text { customers based on their special needs. }\end{array}$ \\
\hline Responsiveness & $\begin{array}{l}\text { The willingness of the staff to provide prompt service and their readiness to } \\
\text { help the customers. }\end{array}$ \\
\hline
\end{tabular}

\section{Students' Satisfaction}

Satisfaction is defined as a state of perception inside the customers after experiencing a service or using a product that fulfils their expectation (Ivashkova and Lopatinskaya 2013). Elliot et al. (2001) defined students' satisfaction as a short-term attitude that reflects the result of having experience with the education service they have received in the institutions. According to llias, Hasan, Rahman, and Yasoa (2008), the students' satisfaction could be affected by the internal and the external factors. In the context of this research, internal factors refer to the teaching staff, learning environment, support facilities, and equipment, whereas external factors refer to the financial and transportation services.

\section{Students' Loyalty}

According to Novatorov and Novitskaya (2012), customers' loyalty could be defined as the intention of the customer to rebuy or reuse the same product or service. Loyalty counts in a process involving the customers' perception, mental, and behaviour (Dehghan et al. 2014). Customers who show loyalty would repurchase a specific brand or give support in a financial or non-financial way to the same product. Similarly, the loyal students would recommend the institution to others and the former students would return to the previous higher education institutions to pursue further study (Marzo-Navarro et al. 2005). To determine the students' loyalty, a model known as the RQSL model was developed by Hennig-Thurau and Klee (1997). This model combines the main elements of the Tinto model $(1975,1993)$ and the relationship quality model. In this model, students' loyalty is determined by three complex constructs which are the students' perception of the quality of the teaching activities, their trust to the institution, and their commitment to the activities organized by the institution.

\section{METHODOLOGY}

This research was a quantitative study whereby a non-experimental survey was conducted from September 2015 to September 2016 to empirically validate the students' satisfaction towards the academic aspects at UTM, Johor Bahru. A descriptive analysis was conducted to determine the 
INTERNATIONAL JOURNAL OF ACADEMIC RESEARCH IN BUSINESS AND SOCIAL SCIENCES

Vol. 8, No. 10, Oct. 2018, E-ISSN: 2222-6990 C 2018 HRMARS

relationship between the independent variable and the dependent variable as portrayed in the research framework (see Figure 2) and to assess the validity of the hypothesis.

The hypothesis of this research are stated as below:

$\mathrm{H}_{1}$ : There are no significant differences in the satisfaction level for international students in Tangibles with loyalty.

$\mathrm{H}_{2}$ : There are no significant differences in the satisfaction level for international students in Reliability with loyalty.

$\mathrm{H}_{3}$ : There are no significant differences in the satisfaction level for international students in Responsiveness with loyalty.

$\mathrm{H}_{4}$ : There are no significant differences in the satisfaction level for international students in Assurance with loyalty.

$\mathrm{H}_{5}$ : There are no significant differences in the satisfaction level for international students in Empathy with loyalty.

In this study, the independent variable was the satisfaction level of the international students towards the service quality in the academic aspects of UTM, while the dependent variable was the students' loyalty.

Figure 2 Theoretical Framework of The Research

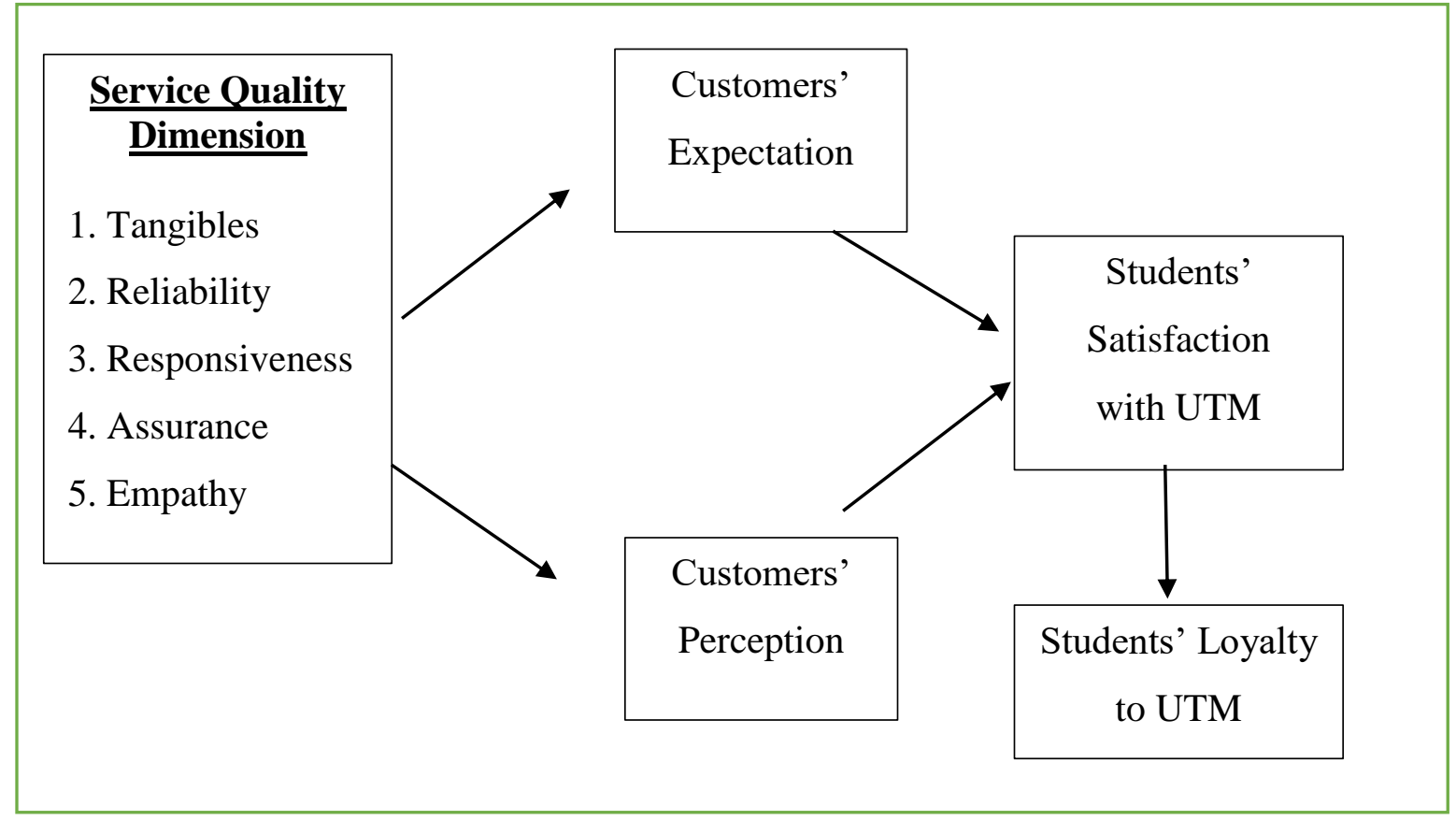

In this study, random sampling technique was used whereby 334 international students were selected as the samples of this study. The instrument was a questionnaire which consisted of three parts with a total of 54 questions. 
INTERNATIONAL JOURNAL OF ACADEMIC RESEARCH IN BUSINESS AND SOCIAL SCIENCES Vol. 8, No. 10, Oct. 2018, E-ISSN: 2222-6990 @ 2018 HRMARS

The first part, Part A contained three items which gathered the respondents' gender and country of origins. Part B consisted of two main SERVQUAL questions where there were 22 items (E1 to E22) exploring the respondents' expectation of the ideal academic service provided in UTM; and another 22 statements (P1 to P22) which evaluated the students' perceptions of the academic services received by them in UTM. These 22 items were adopted from the SERVQUAL instrument (Parasuraman et. al. 1991) and some adjustments were made to measure the academic services in UTM (independent variables). A total of 44 items for the independent variables were used to evaluate the dependent factor, (the students' loyalty) which was measured in Part C via 10 items. The details of each construct were delineated in Table 2.

The questionnaire was ranked using the Likert scale format with the following answers: 1 strongly disagree, 2 disagree, 3 neither, 4 agree, and 5 strongly agree. The Likert scale was used to provide an idea of how the academic services in UTM satisfy the international students by the performance of the service. The items to measure the dependent variable in this study was based on the students' loyalty theory by $\varnothing$ yvind Helgesen and Erik Nesset (2007). There were three variables to measure the students' loyalty, namely recommend (positive word of mouth), repeat, and return. In Table 2, the constructs of the questionnaire and the reliability value of the instrument is presented.

Table 2: Constructs of the questionnaire and reliability value of the instrument

\begin{tabular}{|c|c|c|c|}
\hline CONSTRUCT & ITEM NUMBER & TOTAL & CRONBACH'S ALPHA \\
\hline Tangibles & E1 P1 E2 P2 E3 P3 E4 P4 & 8 & 0.835 \\
\hline Reliability & E5 P5 E6 P6 E7 P7 E8 P8 E9 P9 & 10 & 0.872 \\
\hline Responsiveness & E10 P10 E11 P11 E12 P12 E13 P13 & 8 & 0.830 \\
\hline Assurance & E14 P14 E15 P15 E16 P16 E17 P17 & 8 & 0.821 \\
\hline Empathy & E18 P18 E19 P19 E20 P20 E21 P21 & 10 & 0.765 \\
\hline Loyalty & L1 L2 L3 L4 L5 L6 L7 L8 L9 L10 & 10 & 0.935 \\
\hline & TOTAL & 54 & 0.953 \\
\hline
\end{tabular}

The data obtained from the survey were computed and analyzed using the Statistical Package for Social Science (SPSS) version 18.0. The demographic information, such as the gender and the countries of origin were analyzed using frequency and percentage. In addition, the correlation analysis was conducted to identify the relationship between the five dimensions of SERVQUAL model and multiple regression analysis was used to identify the relationship between the international students' satisfaction level and their loyalty. 
INTERNATIONAL JOURNAL OF ACADEMIC RESEARCH IN BUSINESS AND SOCIAL SCIENCES

Vol. 8, No. 10, Oct. 2018, E-ISSN: 2222-6990 ㄷ 2018 HRMARS

\section{RESULTS AND DISCUSSION}

Table 3 presented the demographic profile of the respondents based on the descriptive analysis.

Table 3 Summary of the Demographic Profile of the Respondents

\begin{tabular}{|c|c|c|c|}
\hline No & Variables & Frequency & Percent \\
\hline \multirow[t]{4}{*}{1} & Gender & & \\
\hline & a. Male & 228 & 68.3 \\
\hline & b. Female & 106 & 31.7 \\
\hline & Total & 334 & 100.0 \\
\hline \multirow[t]{12}{*}{2} & Country of Origin & & \\
\hline & a. Iran & 66 & 19.8 \\
\hline & b. Indonesia & 24 & 7.2 \\
\hline & $\begin{array}{ll}\text { c. } & \text { Nigeria } \\
\end{array}$ & 78 & 23.4 \\
\hline & d. Iraq & 26 & 7.8 \\
\hline & e. $\quad$ Yemen & 41 & 12.3 \\
\hline & f. $\quad$ Pakistan & 31 & 9.3 \\
\hline & g. Sudan & 18 & 5.4 \\
\hline & h. Oman & 10 & 3.0 \\
\hline & i. Bangladesh & 14 & 4.2 \\
\hline & $\begin{array}{ll}\text { j. } & \text { Others } \\
\end{array}$ & 26 & 7.8 \\
\hline & Total & 334 & 100.0 \\
\hline
\end{tabular}

As shown in Table 3, among the 334 respondents, 228 (68.3\%) were males while 106 (31.7\%) were females. In relation to the country of origin, Nigerians constituted the largest number of international students whereby there were 78 (23.4\%) of them participating in the study. Furthermore, $66(19.8 \%)$ students from Iran participated in the questionnaire, constituting the second highest number of international students. Meanwhile, 41 respondents (12.3\%), 31 respondents (9.3\%), and 26 respondents (7.8\%) were from Yemen, Pakistan, and Iraq, respectively. Students from 'other countries' shared the same result with that of Iraq. In addition, there were 24 Indonesian students (7.2\%) and 18 students from Sudan (5.4\%) who participated in the study. In the meantime, 14 students (4.2\%) from Bangladesh and 10 students (3.0\%) from Oman also completed the questionnaire.

Table 4 presented the results of the descriptive analysis of this study. The table outlined the mean and standard deviation of the study variables which were the dimensions of service quality in UTM (tangibles, reliability, responsiveness, assurance, and empathy) and the students' loyalty.

Table 4 Summary of Descriptive Value Results

\begin{tabular}{|c|c|c|}
\hline Variables & Mean & Standard Deviation \\
\hline Tangibles & 3.4431 & 0.74115 \\
\hline Reliability & 3.4042 & 0.77039 \\
\hline Responsiveness & 3.1850 & 0.78239 \\
\hline Assurance & 3.1954 & 0.74624 \\
\hline Empathy & 3.4497 & 0.67866 \\
\hline Students' loyalty & 3.1158 & 0.88644 \\
\hline
\end{tabular}


INTERNATIONAL JOURNAL OF ACADEMIC RESEARCH IN BUSINESS AND SOCIAL SCIENCES Vol. 8, No. 10, Oct. 2018, E-ISSN: 2222-6990 @ 2018 HRMARS

Based on the results, the mean for tangibles, reliability, responsiveness, assurance, empathy, and students' loyalty was 3.4431, 3.4042, 3.1850, 3.1954, 3.4497, and 3.1158, respectively. The average mean showed that the international students were satisfied with 3 variables of the service quality which were the tangibles, reliability, and empathy. Meanwhile, the international students were only slightly satisfied with the two other dimensions, namely the responsiveness and the assurance. Furthermore, the respondents only 'slightly agreed' with the statements about their loyalty to UTM.

To establish the relationship between at least two continuous variables, the Pearson's correlation was utilized. Table 5 showed the proper layout of the correlation analysis result.

Table 5 Correlation Analysis Result

\begin{tabular}{|c|c|c|c|c|c|c|}
\hline & Tangibles & Reliability & Responsiveness & Assurance & Empathy & Loyalty \\
\hline Tangibles (IV1) & 1 & & & & & \\
\hline Reliability (IV2) & $\begin{array}{r}.779^{* *} \\
.000\end{array}$ & 1 & & & & \\
\hline $\begin{array}{l}\text { Responsiveness } \\
\text { (IV3) }\end{array}$ & $\begin{array}{r}.508^{* *} \\
.000\end{array}$ & $\begin{array}{r}.483^{* *} \\
.000\end{array}$ & 1 & & & \\
\hline Assurance (IV4) & $\begin{array}{r}.491^{* *} \\
.000\end{array}$ & $\begin{array}{l}.510^{* *} \\
.000\end{array}$ & $\begin{array}{r}.824^{* *} \\
.000\end{array}$ & 1 & & \\
\hline Empathy (IV5) & $\begin{array}{r}.530^{* *} \\
.000\end{array}$ & $\begin{array}{r}.508^{* *} \\
.000\end{array}$ & $\begin{array}{r}.728^{* *} \\
.000\end{array}$ & $\begin{array}{r}.739^{* *} \\
.000\end{array}$ & 1 & \\
\hline Loyalty (DV) & $\begin{array}{r}.382^{* *} \\
.000\end{array}$ & $\begin{array}{r}.331^{* *} \\
.000\end{array}$ & $\begin{array}{r}.583^{* *} \\
.000\end{array}$ & $\begin{array}{c}.569^{* *} \\
.000\end{array}$ & $\begin{array}{r}.530^{* *} \\
.000\end{array}$ & 1 \\
\hline
\end{tabular}

Note: * Correlation is significant at the 0.05 level (2-tailed)

**. Correlation is significant at the 0.01 level (2-tailed)

The first correlation was between tangibles and students' loyalty whereby the $r$-value was 0.382 or $38.2 \%$ at $99 \%$ confident interval. In accordance with the rule of thumb by Davis (1997), the finding demonstrated that the relationship between these two variables was moderate but positive. Similarly, the correlation between reliability and students' loyalty was 0.331 which signified a moderate and positive relationship between the two variables. Upon further examination of the results, three dimensions, namely responsiveness, assurance, and empathy portrayed a strong relationship with the students' loyalty with an $r$-value of $0.583,0.569$, and 0.530 , respectively. These findings were consistent with the results reported by Brown, R. M., and Mazzarol, T. W. (2009). Additionally, the correlations between all the five dimensions of SERVQUAL (tangibles, reliability, responsiveness, assurance, and empathy) and the international students' loyalty were significant at 0.01 levels (2-tailed). 
INTERNATIONAL JOURNAL OF ACADEMIC RESEARCH IN BUSINESS AND SOCIAL SCIENCES Vol. 8, No. 10, Oct. 2018, E-ISSN: 2222-6990 @ 2018 HRMARS

Table 6 demonstrated the proper layout of the correlation analysis result. Multiple regression analysis is a multivariate system which employs more than one independent variable to enlighten the variance in the dependent variable. It can be used to measure the extent of the relationship between the independent variables and the dependent variable in which the regression coefficients denote the relative importance of every independent variable in the forecast of the dependent variable.

Table 6 Multiple Regression Analysis Result

\begin{tabular}{|c|c|c|c|}
\hline Serial & Independent Variable & $\begin{array}{c}\text { Dependent Variable } \\
\text { (International Students' } \\
\text { Loyalty) }\end{array}$ & $\begin{array}{c}\text { Significance value } \\
\text { (Sig.) }\end{array}$ \\
\hline 1 & Tangibles & 0.121 & 0.094 \\
\hline 2 & Reliability & -0.081 & 0.257 \\
\hline 3 & Responsiveness & $0.278 * *$ & 0.001 \\
\hline 4 & Assurance & $0.213^{*}$ & 0.011 \\
\hline 5 & Empathy & $0.147^{*}$ & 0.037 \\
\hline & & $\begin{array}{l}381 \\
d R^{2}=0.371 \\
=40.327 \\
=0.000^{b}\end{array}$ & ummary \\
\hline
\end{tabular}

As revealed in Table 6, the standard coefficient was 0.121 for tangibles; -0.081 for reliability; 0.278 for responsiveness; 0.213 for assurance; and 0.147 for empathy. R-square, also named as the coefficient of determination, is the scheme of the variance in the dependent variable (international students' loyalty) which could be expected from the independent variables (tangibles, reliability, responsiveness, assurance, and empathy). The adjusted R-square yields a more reliable value to determine the R-square for the population. Based on the results, 38.1\% of the variation in the extent of the international students' loyalty can be predicted from the independent variables. On the other hand, $61.9 \%$ of the variation in the extent of the international students' loyalty were not described in this regression model. Meanwhile, the adjusted R-square of this study was 0.371 .

Furthermore, the analysis revealed that three independent variables, namely responsiveness, assurance, and empathy showed a statistically significant relationship with the extent of the international students' loyalty. The hypotheses were supported because the $p$-value was less than 0.05 for assurance and empathy, while the $p$-value was less than 0.01 for responsiveness. The $p$ values for tangibles and reliability were 0.094 and 0.257 , respectively, implying that their relationships with the students' loyalty were insignificant. This finding indicated that responsiveness, assurance, and empathy could be used to reliably predict the students' loyalty.

\section{CONCLUSION}

The objectives of this research were to: (i) determine the students' satisfaction towards the service quality in UTM and (ii) evaluate the relationship between the students' satisfaction level and their loyalty to UTM. Based on the results, the international students were not satisfied with the quality of service provided in UTM. Overall, the expectations of the students were greater than their 
perceptions in all dimensions of service quality in the SERVQUAL model (tangibles, responsiveness, reliability, empathy, and assurance). In addition, among the five dimensions in SERVQUAL model, only three dimensions (responsiveness, empathy, and assurance) had significant relationships with the students' loyalty.

This study utilized a quantitative approach as the research method. This approach has been frequently used to measure the students' satisfaction and loyalty in numerous studies. Nevertheless, a quantitative study could not capture the sentimental part of the research samples and determine the factors that influence the students' satisfaction and loyalty. Hence, this study proposed future research to adopt a research methodology which combines both quantitative and qualitative approach for data analysis. For example, interview and focus group conversation.

In conclusion, UTM, or for that matter, all higher education institutions should take initiative to improve their service quality to attract and retain more international students. The university administrators should improve the quality of the higher education service based on the dimensions which could affect the students' loyalty. By increasing the students' loyalty, the university could then attract or retain more of their students, be it international or local.

\section{REFERENCES}

Chong, Y.S., Ahmed, P.K. (2012). An empirical investigation of students' motivational impact upon university service quality perception: a self- determination perspective. Quality in Higher Education , 18(1), 37-41.

Dehghan, A., Dugger, J., Dobrzykowski, D., Balazs, A. (2014). The antecedents of student loyalty in online programs. International Journal of Educational Management , 28(1), 15-35.

Galeeva, R.B. (2016). SERVQUAL application and adaptation for educational service quality assessments in Russian higher education. Quality Assurance in Education, 24(3), 329-348.

Hasan, H. F. A., Ilias, A., Rahman, R. A., Razak, M. Z. A. (2009). Service quality and student satisfaction: A case study at private higher education institutions. International Business Research, 1(3), 163.

Helgesen, $\varnothing$., Nesset, E. (2007). Images, satisfaction and antecedents: Drivers of student loyalty? A case study of a Norwegian university college.Corporate Reputation Review, 10(1), 38-59.

Ivashkova, N., Lopatinskaya, I. (2013). Methods of assessment of customer loyalty and satisfaction: adaptation of SERVQUAL analytical capabilities to banking sector. Marketing and Market Research, 103(1).

Kotler, P., Fox, K. F. (1985). Strategic marketing for educational institutions. Prentice-Hall.

Marzo Navarro, M., Pedraja Iglesias, M., Rivera Torres, P. (2005). A new management element for universities: satisfaction with the offered courses.International Journal of educational management, 19(6), 505-526.

Narang, R. (2012). How do management students perceive the quality of education in public institutions? Quality Assurance in Education , 20(4), 357-371.

Novatorov, E., Novitskaya, V. (2012). Modification and empirical test of SERVQUAL method of service quality assessment for banking services. Marketing in Finance and Insurance, 1.

Oliver, R. L., Rust, R. T., Varki, S. (1997). Customer delight: foundations, findings, and managerial insight. Journal of retailing, 73(3), 311-336. 
Oliver, R. L., Swan, J. E. (1989). Equity and disconfirmation perceptions as influences on merchant and product satisfaction. Journal of consumer research, 16(3), 372-383.

Parasuraman, A., Zeithaml, V. A., Berry, L. L. (1988). Servqual. Journal of retailing, 64(1), 12-40.

Parasuraman, A., Zeithaml, V. A., Berry, L. L. (1985). A conceptual model of service quality and its implications for future research. the Journal of Marketing, 41-50.

Rezaei, S., Matin, B.K., Hajizadeh, M., Soroush, A., Mohammadi, Z., Babakhany, M., Jamshidi, K. (2017). Evaluating service quality in the higher education sector in Iran: an examination of students' perspective. International Journal of Human Rights in Healthcare, 10(2), 146-155.

Wong, K. , Tunku, U., Rahman, A. (2012). Constructing a survey questionnaire to collect data on service quality of business academics. European Journal of Social Sciences , 29(2), 209-221.

Zeithaml, V. A., Berry, L. L., Parasuraman, A. (1993). The nature and determinants of customer expectations of service. Journal of the academy of Marketing Science, 21(1), 1-12.

Zeithaml, V. A., Berry, L. L., Parasuraman, A. (1996). The behavioral consequences of service quality. the Journal of Marketing, 31-46. 